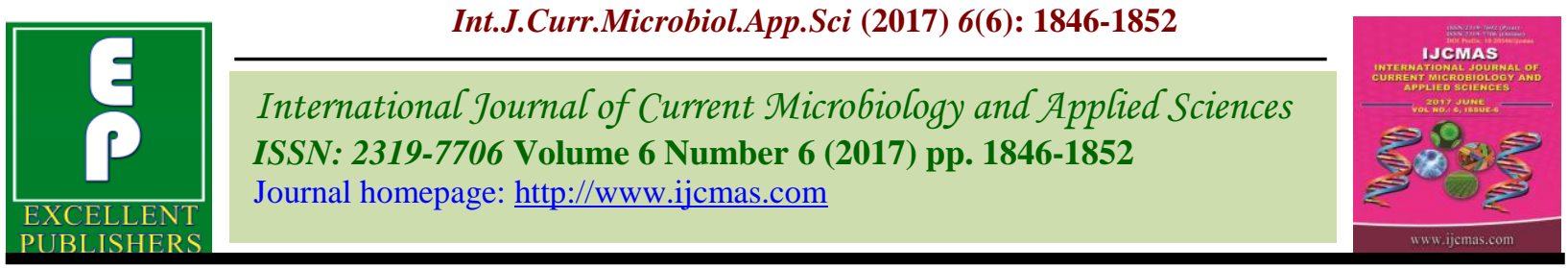

Original Research Article

https://doi.org/10.20546/ijcmas.2017.606.215

\title{
Novel Biofilm Biofertilizers for Nutrient Management and Fusarium Wilt Control in Chickpea
}

\author{
M. Nissipaul", Sodimalla Triveni, R. Subhashreddy and B. Suman \\ Department of Agricultural Microbiology and Bioenergy, College of Agriculture, \\ Ragendranagar, Hyderabad, India \\ *Corresponding author
}

\section{A B S T R A C T}

Wilt caused by Fusarium oxysporium $f$. spciceris is a devastating disease of chickpea. It occurs in 2 stages; seedling stage (0-30\%) and reproductive stage (0-57\%). Annual chickpea yield loss due to Fusarium wilt was estimated to be $10 \%$ in India. So, our objective is to control chickpea wilt disease by using Trichoderma based biofilms as an

\begin{tabular}{|l|}
\hline Ke y w or d s \\
Biofertilizers, \\
Nutrient, \\
Management \\
and Chickpea \\
\hline Article Info \\
\hline $\begin{array}{l}\text { Accepted: } \\
\text { 23 May 2017 } \\
\text { Available Online: } \\
\text { 10 June 2017 }\end{array}$ \\
\hline \hline
\end{tabular}
alternative to chemical fungicides. Trichoderma viride is a potential antagonistic fungi which prevents diseases like wilt, brown rot, damping off, charcoal rot etc. We have isolated different strains of PGPR bacteria from waste lands of Parthenium rhizosphere soils to prepare a biofilm. A biofilm is an aggregate of microorganisms in which cells are stuck to each other and/or to biotic/abiotic surface. Our work was aimed towards the development of biofilms under in vitro conditions, using a combination of agriculturally important potential microorganisms like Bacillus subtilis, Pseudomonas flourescens and Rhizobium leguminosarum with the fungus Trichoderma viride as the matrix and screened for various biochemical traits like Antifungal activity, Ammonia production, HCN production, IAA production, Protein content, Siderophore production and Phosphate solubilization; and when compared to individual treatments, coinoculations and biofilms the biofilm performed well in all the biochemical properties. These biofilms were evaluated for their disease management and crop production in chickpea. A field experiment which comprised of 9 treatments were conducted. The synergism in terms of the PGP traits in the biofilms revealed their promise as superior PGP inoculants hence this in vitro experiment is to be carried out under field conditions to show better results.

\section{Introduction}

The chickpea or chickpea (Cicer arietinum) is a legume of the family Fabaceae, subfamily Faboideae. It is also known as gram or Bengal gram, Garbanzoor garbanzo bean and sometimes known as Egyptian pea, ceci, cece or chana. Its seeds are high in protein. It is one of the earliest cultivated legumes: 7,500year-old remains have been found in the Middle East. The fungus Fusarium oxysporium enters the vascular system of the infected plant via the roots. It produces enzymes that degrade the cell walls so that gels are formed that block the plant's transport system. Discolouration of the internal tissues progresses from the roots to the aerial parts of the plant, yellowing and wilting of the foliage occur, and finally there is necrosis. Biofilms represents complex communities of multiple microbial species which remain attached to surfaces or at the 
interfaces (Lynch et al., 2003), and possess the capacity to maintain the metabolic activity under adverse environmental conditions, exhibiting increased survival in a competitive environment (Stewart, 2002). Biofilms comprise layers of prokaryotic or eukaryotic cells, which can also play a key role in plantmicrobe interactions, promote plant growth and reduced.

\section{Materials and Methods}

\section{Phosphate solubilization}

Sterilized Pikovskaya's agar medium was poured as a thin layer in the sterilized Petri plates and allowed for solidification. The Pikovskaya's plates were spot inoculated with 11 isolates of Bacillus spp., Pseudomonas spp., Rhizobium spp., incubated at $28 \pm 22^{0} \mathrm{C}$ for 2-3 days. Formation of a clear zone around the colonies was considered as positive result for phosphate solubilisation. It was calculated by following formula.

PSE (Phosphate Solubilization Efficiency) = $\mathrm{ZC} \times 100$

$\mathrm{Z}$ - Clear zone including bacterial growth

$\mathrm{C}$ - Colony diameter

\section{Ammonia production}

The isolates were tested for Ammonia production by inoculating the isolates in to 10 $\mathrm{ml}$ of sterilized peptone water in the test tubes. The tubes were incubated for $48-72 \mathrm{~h}$ at $36 \pm 2^{\circ} \mathrm{C}$. After that Nessler's reagent $(0.5 \mathrm{ml})$ was added in each tube. Change in colour of the medium from brown to yellow colour was taken as positive test for Ammonia production.

\section{Indole Acetic Acid Production}

Indole acetic acid production was tested according to Gorden and Weber (1951). The active culture of each test isolate was raised in $5 \mathrm{ml}$ respective broth tubes and incubated at determined temperature and time. After incubation these cultures were centrifuged at recommended rpm and time. Two drops of Ophosphoric acid was added to $2 \mathrm{ml}$ of supernatant to develop the colour. Development of pink colour considered as positive test for IAA production.

\section{Protien estimation}

One $\mathrm{ml}$ of the sample was taken and cells were pelleted by centrifuging at $10,000 \mathrm{rpm}$ for $8 \mathrm{~min}$. Spectrophotometric measurement of colour development was done using the method of Lowry et al., (1951). Intensity of blue colour was measured at absorbance maxima of $660 \mathrm{~nm}$.

\section{Siderophore production}

Siderophore production was estimated qualitatively. By taking $0.5 \%$ of cell free culture supernatant and added to $0.5 \mathrm{ml}$ of $0.2 \%$ aqueous Ferric chloride solution. Appearance of orange or reddish brown colour indicated the presence of Siderophore (Yeole and Dube 2000).

\section{Hydrogen cyanide production}

The HCN production was done by the method of Castric and Castric (1983). Medium platesi.e. Nutrient agar for B. subtilis, Kings B for $P$. flourescens, YEMA for $R$. leguminosarum, were prepared separately and incubated for $24 \mathrm{~h}$. One $\mathrm{ml}$ of culture of each test isolate was inoculated on respective media plates separately. A disc of Whatman filter paper No. 1 of the diameter equal to the Petri plate size, impregnated with alkaline picric acid solution $(0.5 \%$ picric acid $(\mathrm{w} / \mathrm{v})$ in $1 \%$ sodium carbonate) was placed in the upper lid of the inoculated Petri plates under aseptic condition. The control plate did not receive the inoculum. The plates were 
incubated at $28 \pm 2{ }^{\circ} \mathrm{C}$ for $48-72 \mathrm{~h}$. Change in colour from yellow to light brown, moderate or strong reddish brown was taken as an indication of $\mathrm{HCN}$ production.

\section{Antagonistic activity}

Antagonistic activity was studied by following dual culture technique (Skidmore and Dickinson, 1976). First, the bacterial cultures were streaked on respective media plates and incubated at respective temperature and time. Then take a loopful of each bacterial culture and streak on the Nutrient agar plate at one end, and place $5 \mathrm{~mm}$ mycelial disc of test pathogen at the other end. Control plate was maintained by placing only pathogen mycelial disc on the plate without bacteria.

The assay of plates were incubated at $28 \pm 2$ ${ }^{\circ} \mathrm{C}$ for 5 days and observations were made on inhibition of mycelial growth of the test pathogens. For each bacterial isolate three replications were maintained with suitable controls. The per cent growth inhibition over control was calculated by using the formula:

Percent Inhibition $=$ $\frac{\text { Growth of Pathogen in control }(\mathrm{mm})-\text { Growth of Pathogen in treatment }(\mathrm{mm})}{\text { Growth of Pathogen in control(mm) }} \times 100$

Note: The percent inhibition in control is taken as zero percent.

\section{Results and Discussion}

\section{Biochemical attributes of Biofilms related to PGP activity}

All the 7 B. subtilis and $2 P$. flourescence individual isolates/dual cultures/biofilms were able to form clear zone of phosphate solubilisation on agar plate ranged from 10-19 $\mathrm{mm}$ with highest zone of solubilisation efficiency (170\%) efficiency is observed in
T8 (Trichoderma viride+ Rhizobium leguminosarum $+\quad$ Pseudomonas fluorescence+ Bacillus subtilis (Biofilm) (Table 1).

All the cultures used were found to be Ammonia producers and based on the development of yellow colour they were classified as weak, moderate, and strong. Except $T$. viride, $\mathrm{B} 1$, and $\mathrm{B} 4$, all the individual cultures/ dual cultures and biofilms. It is able to produce HCN. All the individual isolates, dual cultures, biofilms had shown the IAA production and based on the intensity of pink color development they are classified.

Protein estimation was done by spectrophotometric measurement of blue colour development at absorbance maxima of $660 \mathrm{~nm}$. The highest values for proteins were recorded in $\mathrm{T}_{4}$ (Trichoderma viride + Pseudomonas fluorescence (Biofilm), (0.41 $\mathrm{mg} \mathrm{ml}^{-1}$ ) and the lowest was recorded with $\mathrm{T}_{9}$ (Trichoderma viride + Rhizobium leguminosarum + Pseudomonas fluorescence + Bacillus subtilis (Coinoculation) $(0.28 \mathrm{mg}$ $\mathrm{ml}^{-1}$ ) and B2 of B. subtilis. Protein estimation was not observed in $T$. viride individual isolate.

The production of siderophores was observed with all the treatments and is more or less equal. The more production of siderophores was recorded with the treatments $\mathrm{T}_{2}$ (Trichoderma viride + Rhizobium leguminosarum (Biofilm) and the lowest were recorded in T5, T6. In the present study, all the PGPR individual isolates/dual cultures and biofilm cultures were examined for the potential to inhibit fungal pathogen Fusarium oxysporum under in vitro conditions. Each isolate having some percent inhibition, with some inhibition zone. The highest percent inhibition $(37.15 \%)$ was recorded in $\mathrm{T}_{8}$ (Trichoderma viride + Rhizobium 
leguminosarum + Pseudomonas fluorescence + Bacillus subtilis (Biofilm) with an inhibition zone of $(03.00 \mathrm{~mm})$ and the next best is $\mathrm{T}_{9}$ and $\mathrm{T}_{4}(36.6 \%)$ and inhibition zone of $(3.01 \mathrm{~mm})$. The lowest inhibition was recorded in $\mathrm{T}_{2} R$. leguminosarum $+T$. viride biofilms and its dual culture $T_{5}$ with percent inhibition of $31.65 \%$ and $29.95 \%$ respectively (Table 2). Kerkar et al., (2012) reported that out of the 125 bacteria isolated from the biofilms, 16 produced indole-3acetic acid (IAA). Four isolates consistently produced high IAA concentrations ranging from 9.5 to $14.2 \mu \mathrm{g} \mathrm{mL}^{-1}$ in the presence of 4 $\mathrm{mg} \mathrm{mL} \mathrm{m}^{-1}$ tryptophan concentrations in the growth media (Tale 3 ).

Table.1 In vitro screening of biofilms for various plant growth promoting attributes

\begin{tabular}{|c|c|c|c|c|c|c|c|}
\hline \multirow[t]{3}{*}{ S.No. } & \multirow[t]{3}{*}{ Treatments } & \multicolumn{3}{|c|}{ Phosphate solubulisation } & \multirow{3}{*}{$\begin{array}{l}\text { Ammonia } \\
\text { production }\end{array}$} & \multirow{3}{*}{$\begin{array}{l}\text { IAA } \\
\text { production }\end{array}$} & \multirow{3}{*}{$\begin{array}{l}\text { Protein } \\
\text { estimation } \\
\left(\mathrm{mg} \mathrm{ml}^{-1}\right)\end{array}$} \\
\hline & & \multicolumn{2}{|c|}{ Zone diameter } & \multirow{2}{*}{$\begin{array}{l}\text { Solubulisation } \\
\text { efficiency }\end{array}$} & & & \\
\hline & & $\begin{array}{l}\text { Solubulisation } \\
\text { Zone }\end{array}$ & $\begin{array}{l}\text { Culture } \\
\text { media }\end{array}$ & & & & \\
\hline 1 & $\mathrm{~T}_{1}$ & - & - & - & - & - & - \\
\hline 2 & $\mathrm{~T}_{2}$ & - & - & - & ++ & ++ & 0.29 \\
\hline 3 & $\mathrm{~T}_{3}$ & 24 & 13 & 184.6 & +++ & +++ & 0.30 \\
\hline 4 & $\mathrm{~T}_{4}$ & 20 & 11 & 181 & +++ & +++ & 0.41 \\
\hline 5 & $\mathrm{~T}_{5}$ & - & - & - & ++ & ++ & 0.30 \\
\hline 6 & $\mathrm{~T}_{6}$ & 19 & 14 & 135.5 & ++ & ++ & 0.29 \\
\hline 7 & $\mathrm{~T}_{7}$ & 20 & 12 & 166.6 & ++ & +++ & 0.39 \\
\hline 8 & $\mathrm{~T}_{8}$ & 21 & 11 & 190 & +++ & +++ & 0.29 \\
\hline 9 & $\mathrm{~T}_{9}$ & 24 & 13 & 184.6 & +++ & +++ & 0.28 \\
\hline
\end{tabular}

IAA- Indole Acetic Acid Ammonia production

+ Weak production ++ Moderate production

+++ Strong production - No production

Table.2 In vitro screening of efficient biofilms for bio control activity

\begin{tabular}{|c|c|c|c|c|c|}
\hline \multirow{2}{*}{ S. No. } & Treatments & $\begin{array}{c}\text { Antifungal activity } \\
\text { Fusarium }(\%)\end{array}$ & $\begin{array}{c}\text { Inhibition } \\
\text { zone (mm) }\end{array}$ & $\begin{array}{c}\text { Siderophore } \\
\text { production }\end{array}$ & $\begin{array}{c}\text { HCN } \\
\text { production }\end{array}$ \\
\cline { 3 - 4 } & $\mathrm{T}_{1}$ & - & - & - & - \\
\hline 1 & $\mathrm{~T}_{2}$ & 31.65 & 00 & +++ & ++ \\
\hline 2 & $\mathrm{~T}_{3}$ & 34.40 & 01.00 & +++ & +++ \\
\hline 3 & $\mathrm{~T}_{4}$ & 36.6 & 03.01 & +++ & +++ \\
\hline 4 & $\mathrm{~T}_{5}$ & 29.95 & 00 & ++ & ++ \\
\hline 5 & $\mathrm{~T}_{6}$ & 33.85 & 01.00 & ++ & ++ \\
\hline 6 & $\mathrm{~T}_{7}$ & 36.05 & 03.00 & +++ & +++ \\
\hline 7 & $\mathrm{~T}_{8}$ & 37.15 & 03.00 & +++ & +++ \\
\hline 8 & $\mathrm{~T}_{9}$ & 36.6 & 03.01 & +++ & ++ \\
\hline 9 & & & & \\
\hline
\end{tabular}

HCN- Hydrogen cyanide Siderophore production

+ Weak production ++ Moderate production

+++ Strong production - No production 
Table.3 Effect of Biofilmed biofertilisers on plant growth parameters in chick pea

\begin{tabular}{|l|l|l|l|l|l|l|}
\hline \multirow{2}{*}{ Treatments } & \multicolumn{2}{l|}{ Plant height $(\mathbf{c m})$} & \multicolumn{2}{l|}{ Root length $(\mathbf{c m})$} & Shoot dry Wt $(\mathbf{g})$ & Root dry Wt $(\mathbf{g})$ \\
\cline { 2 - 7 } & 30 DAS & $\mathbf{6 0}$ DAS & 30 DAS & 60 DAS & Average & Average \\
\hline $\mathrm{T}_{1}$ & 13.27 & 23.93 & 6.53 & 12.90 & 2.18 & 0.35 \\
\hline $\mathrm{T}_{2}$ & 14.37 & 28.23 & 8.13 & 16.00 & 3.55 & 0.54 \\
\hline $\mathrm{T}_{3}$ & 13.83 & 28.30 & 7.93 & 14.47 & 3.33 & 0.47 \\
\hline $\mathrm{T}_{4}$ & 14.40 & $\mathbf{2 9 . 4 3}$ & 8.27 & 15.73 & 3.54 & 0.48 \\
\hline $\mathrm{T}_{5}$ & 13.93 & 27.97 & 7.87 & 14.33 & 3.55 & 0.51 \\
\hline $\mathrm{T}_{6}$ & 13.37 & 27.40 & 7.33 & 13.50 & 3.08 & 0.44 \\
\hline $\mathrm{T}_{7}$ & 14.27 & 28.53 & 7.87 & 14.33 & 3.27 & 0.46 \\
\hline $\mathrm{T}_{8}$ & $\mathbf{1 4 . 7 7}$ & $\mathbf{2 9 . 4 3}$ & $\mathbf{8 . 4 3}$ & $\mathbf{1 7 . 4 0}$ & $\mathbf{4 . 1 2}$ & $\mathbf{0 . 6 1}$ \\
\hline $\mathrm{T}_{9}$ & 14.67 & 28.67 & 8.37 & 16.30 & 4.09 & 0.57 \\
\hline $\mathrm{SEm}$ & 0.27 & 0.72 & 0.26 & 0.41 & 0.19 & 0.03 \\
\hline $\mathrm{CD}(\mathrm{P}=0.05)$ & 0.84 & 2.17 & 0.80 & 1.26 & 0.57 & 0.11 \\
\hline
\end{tabular}

Table.4 Effect of Biofilmed biofertilisers on disease suppression (Fusarium wilt) in chickpea

\begin{tabular}{|l|l|l|l|}
\hline Treatments & $\begin{array}{l}\text { Initial plant } \\
\text { population }\end{array}$ & $\begin{array}{l}\text { Final plant } \\
\text { population }\end{array}$ & $\begin{array}{l}\text { Wilt Incidence } \\
(\%)\end{array}$ \\
\hline $\mathrm{T}_{1}$ & 360 & 285 & $\mathbf{2 0 . 7}$ \\
\hline $\mathrm{T}_{2}$ & 385 & 349 & 9.3 \\
\hline $\mathrm{T}_{3}$ & 382 & 352 & 8.0 \\
\hline $\mathrm{T}_{4}$ & 386 & 381 & 1.3 \\
\hline $\mathrm{T}_{5}$ & 380 & 329 & 13.7 \\
\hline $\mathrm{T}_{6}$ & 372 & 337 & 9.3 \\
\hline $\mathrm{T}_{7}$ & 380 & 363 & 4.7 \\
\hline $\mathrm{T}_{8}$ & $\mathbf{4 0 0}$ & $\mathbf{3 9 7}$ & 1.1 \\
\hline $\mathrm{T}_{9}$ & 389 & 380 & 2.2 \\
\hline $\mathrm{SEm}$ & 6.52 & 8.56 & 2.06 \\
\hline $\mathrm{CD}(\mathrm{P}=0.05)$ & 2.96 & 4.20 & 45.51 \\
\hline
\end{tabular}

Table.5 Effect of Biofilmed biofertilisers on yield and yield attributing characters of chickpea

\begin{tabular}{|l|l|l|l|}
\hline Treatments & $\begin{array}{l}\text { Number of pods } \\
\text { per each plant }\end{array}$ & Test weight $(\mathbf{g})$ & Seed yield $\left(\mathbf{k g ~ h a}^{-\mathbf{1}}\right)$ \\
\hline $\mathrm{T}_{1}$ & 13.7 & 18.9 & 780 \\
\hline $\mathrm{T}_{2}$ & 16.7 & 19.8 & 1255 \\
\hline $\mathrm{T}_{3}$ & 16.3 & 19.4 & 1181 \\
\hline $\mathrm{T}_{4}$ & 17.0 & 19.9 & 1278 \\
\hline $\mathrm{T}_{5}$ & 15.7 & 19.2 & 1138 \\
\hline $\mathrm{T}_{6}$ & 15.0 & 19.1 & 1020 \\
\hline $\mathrm{T}_{7}$ & 16.7 & 19.3 & 1158 \\
\hline $\mathrm{T}_{8}$ & $\mathbf{1 7 . 7}$ & $\mathbf{2 0 . 6}$ & $\mathbf{1 4 0 9}$ \\
\hline $\mathrm{T}_{9}$ & 17.3 & 19.8 & 1334 \\
\hline $\mathrm{SEm}$ & 0.50 & 0.14 & 14.22 \\
\hline $\mathrm{CD}(\mathrm{P}=0.05)$ & 1.54 & 1.26 & 21.10 \\
\hline
\end{tabular}

Shaban and EI- Bramaway (2011) studied the biological control of damping off and root rot causing fungi ( $F$. oxysporum, $F$. solani, Macrophomina phaseolina, Rhizoctonia solani and Sclerotium rolfsii) with antagonistic organisms (Rhizobium and Trichoderma spp). Results revealed that combined effect of both Rhizobium spp. and 
Trichoderma spp. were found to be beneficial in controlling the fungal diseases of legume crops.

Evaluation of disease and nutrient management of chickpea under field conditions

Effect of biofilmed biofertilisers on different plant growth parameters

Highest plant height $(14.7 \mathrm{~cm}$ and $29.43 \mathrm{~cm})$, root length $(8.43 \mathrm{~cm}$ and $17.40 \mathrm{~cm})$, shoot $(4.12 \mathrm{~g})$ and $\operatorname{root}(0.61 \mathrm{~g})$ dry weight of chickpea were analysed at 30 and 60 days after sowing was recorded in $\mathrm{T}_{8}$ (Trichoderma viride + Rhizobium + Pseudomonas fluorescence + Bacillus subtilis (Biofilm) with when compared to all other treatments.

Karnwal and Kumar (2012) reported that shoot length and dry matter increased up to 43 $\%$ of chickpea after inoculation with Plant growth promoting rhizobacteria (PGPR) increased up to $92 \%$ in comparison with control.

\section{Effect of biofilmed biofertilisers on disease suppression (Fusarium wilt) in chickpea}

Germination percentage of chickpea seeds is $100 \%$ under in vitro conditions but under field conditions it is $77-95 \%$. The difference in the initial population and final population was recorded due to the attack of Fusarium wilt during the crop growth. The lowest percent wilt incidence was recorded in $\mathrm{T}_{8}(T$. viride $+R$. leguminosarum $+P$. fluorescence+ B. subtilis (Biofilm) i.e. (1.1 $\%)$ which is on par with $\mathrm{T}_{4}(1.3 \%)$ and then followed by $\mathrm{T}_{9}(T$. viride $+R$. leguminosarum + P. fluorescence + B. subtilis (Coinoculation) (2.2\%). The highest percent of wilt occurrence was observed in $\mathrm{T}_{1}$ (control) (20.7 $\%)$.

Similar results were reported by Leo et al.,
(2012) where they conducted on-farm demonstration by using Trichoderma viride, PSB and Rhizobium to study the effect on wilt incidence, yield and related parameters. Seeds were treated with PSB + Rhizobium $+T$. viride followed by soil application of $T$. viride + PSB + Rhizobium after 30 DAS (mixed with $200 \mathrm{~kg}$ of FYM), wilt incidence was (3.3 $\%$ ) when compared to the other individual treatments and for control where the wilt incidence was (18.1\%) (Table 4).

Effect of Biofilmed biofertilisers on yield and yield attributing characters of chickpea

At harvest significantly highest number of pods (17.67) per plant, maximum weight of 100 seeds $(20.58 \mathrm{~g})$, seed yield (1409 $\left.\mathrm{kg} \mathrm{ha}^{-1}\right)$ was recorded in the treatment $\mathrm{T}_{8}$ ( $T$. viride+ $R$. leguminosarum $+P$. fluorescence $+B$. subtilis (Biofilm) compared to all other treatments (Table 5).

Similar results were reported by Wani et al., (2007). They showed that Mesorhizobium ciceri and phosphate-solubilizing rhizobacteria promoted plant growth, grain yield and nutrient uptake by field grown chickpea.

Das et al., (2013) reported that the combined inoculation of Rhizobium and PSB significantly enhanced growth, yield attributes, yield, nutrient content and their uptake in seed and straw of chickpea.

\section{References}

Castric, K.F and Castric, P.A. 1983. Method for rapid detection of cyanogenic bacteria. Applied and Environmental Microbiology. 45: 700-702.

Das, S., Pareek, B.L., Amit, K., Ram, D.S. 2013. Effect of phosphorus and biofertilizers on productivity of 
chickpea (Cicer arietinum L.) in north western Rajasthan, India. Legume Research: An International Journal. 36(6): 5-11

Gorden, A.S and Weber, R.P. 1951. Colorimetric estimation of Indole Acetic Acid. Plant Physiology. 26: 192195.

Karnwal, A and Kumar, V. 2012. Influence of Plant Growth Promoting Rhizobacteria (PGPR) on the growth of Chickpea (Cicer arietinum L.). Annals of Food Science and Technology.

Kerkar, S., Raiker, L., Tiwari, A., Mayilraj, S and Dastager, S. 2012.Biofilm associated indole acetic acid producing bacteria and their impact in the proliferation of biofilm mats in solar salterns. Biologia.vol.67 (3); 454-460.

Lowry, O.H., Rosebrough, N.J., Farr, A.L., Randall, R.J. 1951. Protein measurement with folin-phenol reagent. Journal of Biology and Chemistry. 193: 265-275.

Lynch, JF Lappin S, Hilary M, Costerton, JW 2003. Microbial biofilms. Cambridge University press, Cambridge, UK.

Shaban, W.I and El-Bramawy, M.A. 2011.Impact of dual inoculation with
Rhizobium and Trichoderma on damping off, root rot diseases and plant growth parameters of some legumes field crop under greenhouse conditions. International Research Journal of Agricultural Science. 1 (3): 098-108.

Skidmore, A.M and Dickinson, C.H. 1976.Colony interaction and hyphal interference between Septoria nodorum and phylloplane fungi. Transactions and Journal of the British Ceramic Society. 66: 57-74.

Stewart PS 2002.Mechanisms of antibiotic resistance in bacterial biofilms. International Journal of Medical Microbiology.292:107-113.

Supraja, Y., Reddy, R.S., Reddy, S.S and Rani, Ch.V.D. 2011.Plant growth promotion and biocontrol properties of local isolates of fluorescent Pseudomonads. Journal of Research ANGRAU. 39 (3): 1-5.

Yeole, R.D., Dube, H.C. 2000.Siderophore mediated antibiosis of rhizobacterial fluorescent Pseudomonas against certain soil borne fungal plant pathogens. Journal of Mycology and Plant Pathology.30 (3): 335-338.

\section{How to cite this article:}

Nissipaul, M., Sodimalla Triveni, R. Subhashreddy and Suman, B. 2017. Novel Biofilm Biofertilizers for Nutrient Management and Fusarium Wilt Control in Chickpea. Int.J.Curr.Microbiol.App.Sci. 6(6): 1846-1852. doi: https://doi.org/10.20546/ijcmas.2017.606.215 